\title{
Behavior of Retail Investors towards Financial Investments (with Special Reference to Bhopal) towards Various Investment Alternatives
}

\section{Ajaz Ahmad Bhat*}

Department of Commerce, Barkatullah University, India

\begin{abstract}
This paper is going to makes a pertinent revelation that the behavior of retail investors towards financial investment is quite different but this paper will extract is really the knowledge and awareness differs the retail investors taste towards the investment options in terms of getting the return out of the employed amount to the respective options, for the completion of this paper I had employed the questionnaire for sampling and for recording the responses accordingly for the further interpretation and analysis in Bhopal city on 300 respondents respectively, the objective of this paper is to know the behavior of retail investor and experience of investors does really matters in terms of return and capital appreciation, for completion of this paper I applied simple randomly sampling, tools are employed like percentile method, chi square test.
\end{abstract}

Keywords: Investment; Return; Behavior; Income; Experience; Gender; Residence; Investor alternatives

\section{Introduction}

The term investment is used to convert the money or cash into the future return or claim the profit on future as return. Investment is an application which is used to claim the return and saving the future, Now I days stock exchange are the major attractions for investors to invest into shares, bonds etc. the investments decision have become more risky, more new entrants have entered into the capital markets with attractive screams of investments [1]. As the size and volume of investors have increase and the capital markets have expanded rapidly, malpractices have increased tremendously; the investment in the stock market is very risky because the ultimate losers are always the house hold investor.

\section{Types of investors}

1. Controlling shareholders/investors: This may comprise an individual a family, or group of corporations acting through a holding company or cross shareholders, by having a substantial shareholding, they can influence the working of the corporation.

2. Non-Institutional or individual shareholder/investors: They are widely scattered group of individuals holding small amounts of shares are known as minority shareholders.

3. Institutional shareholders: They represent an organized and highly motivated group, they are being dependent upon to improve the quality of governance in the corporation.

Flow chart draw shows the different categories of investors which includes the individuals and professional individual investors are those who invest their own savings while professional investors are those who manage the funds on behalf of others, like mutual funds provident funds etc. the individual were further divided into two categories. The first is the experienced investors who need to be properly advised about the intricacies of investment in industrial securities. The second one is experienced investor who understand the risks involved in investment and who need no advices [2].

\section{Categories of investors}

Individual investors
a. Inexperienced.
b. Experienced.
c. Professional.

\section{Financial investments}

Before investing into the stock market, the investors have some concepts in mind regarding its working and all in this process he suffers various myths, i.e., he thought something to be true but actual they are his myth and the reality is something different.

\section{Research Methodology}

The study has been conducted on 300 samples through stratified simple random sampling method of different financial marketing areas of Bhopal district (Madhya Pradesh). The data for analysis was collected from March to August 2017 to check the behavior of retail investors towards various financial investments.

\section{Statistical tools}

For the purpose of the study some tools statistical tools like calculation of percentage, average, chi -square test and other necessary methods like mean mode and median.

\section{Objectives of the study}

To study the behavior of retail investors towards various financial investments.

To study the profile of retail investors towards the various financial investments.

*Corresponding author: Ajaz Ahmad Bhat, Research Scholar, Department of Commerce, Barkatullah University, Bhopal, India, Tel: 9149436440; E-mail: bhatajazg@gmail.com

Received April 05, 2018; Accepted May 01, 2018; Published May 10, 2018

Citation: Bhat AA(2018) Behavior of Retail Investors towards Financial Investments (with Special Reference to Bhopal) towards Various Investment Alternatives. J Bus Fin Aff 7: 336. doi: 10.4172/2167-0234.1000336

Copyright: () 2018 Bhat AA. This is an open-access article distributed under the terms of the Creative Commons Attribution License, which permits unrestricted use, distribution, and reproduction in any medium, provided the original author and source are credited. 
Citation: Bhat AA (2018) Behavior of Retail Investors towards Financial Investments (with Special Reference to Bhopal) towards Various Investment Alternatives. J Bus Fin Aff 7: 336. doi: 10.4172/2167-0234.1000336

Page 2 of 8

\section{Hypothesis}

- Hypothesis 1: There is no significant difference between the gender of retail investors towards various financial investments.

- Hypothesis 2: There is no significant difference between the occupations of retail investors towards various financial investments.

\section{Retail investors behavioral profile}

The retail investors behavioral profile provides a combination of characteristics based on personality traits of retail investors behavior including age, education, occupation, family size, gender, marital status, sources of income, experience of investment, residence of retail investors, knowledge about investment, investment patterns [3].

Age of respondents: Age of the respondents (retail investors) is one of the most important characteristics to understanding their views about particular conditions. Age is an important factor of retail investors that indicates the level of maturity towards various financial investments, in that sense age becomes more important to examine the response from the respondents towards the particular situations (Table 1).

Interpretation: The above table data indicates the age of the 300 respondents separately. $74 \%$ respondents are those whose age is $20-40$ age group, $21 \%$ respondents are those whose age is in between the 40 60 age group and $4.3 \%$ respondents are those who age is 60 and above, so, we understood from the data that the investors are mostly from 20-40 of age group and are young and passionate who can invest their present savings or funds for better future (Figure 1).

Gender profile of the investors: The Sex of respondents is one of the main factors which determine the behavior of retail investors. According, to the sex distribution they both behave separately towards the financial investment as per their perceptions and investment behavior (Table 2).

Interpretation: The above table shows that there are 300 respondents and out of them there are $58.7 \%$ male respondents and their value is (176) and $41.3 \%$ respondents are females and their value is (124).

\begin{tabular}{|c|c|c|c|c|c|}
\hline S.No & Variable & Frequency & Percent & $\begin{array}{c}\text { Valid } \\
\text { Percent }\end{array}$ & $\begin{array}{c}\text { Cumulative } \\
\text { Percent }\end{array}$ \\
\hline 1 & $20-40$ & 222 & 74 & 74 & 74 \\
\hline 2 & $40-60$ & 65 & 21.7 & 21.7 & 95.7 \\
\hline 3 & above 60 & 13 & 4.3 & 4.3 & 100 \\
\hline & Total & 300 & 100 & 100 & \\
\hline
\end{tabular}

Source: Primary survey

Table 1: Age of the respondent.

\section{Age of respondents in Percentage}

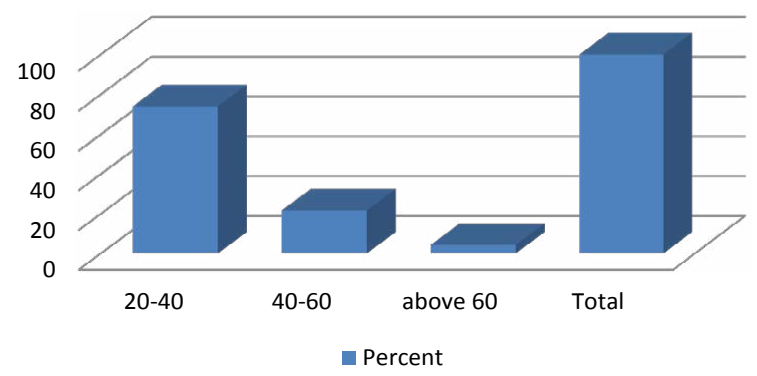

Figure 1: Age of the respondent.
So, the data indicated that male investor is more investing than female investors. As the percentage of male gender is $58.7 \%$ which is higher than the female gender i.e., $41.3 \%$ (Figure 2).

Educational background of the respondents: Education as an important characteristic that affect the person's attitude and the way of looking and understanding and monitoring the particular socioeconomic and financial situations. In this way, the behavior towards any situation of an individual is likely to be determined by his education and therefore it becomes important to know the educational background of the respondents. Hence the variable 'educational background' was investigated by the researcher and the data pertaining to education is presented in the table (Table 3) [4].

Interpretation: The data interpretation of the above table shows the layout of the education background of respondents. So, far as the education of the respondents is concerned, $30.7 \%$ of respondents (retail investors) are those who are having school education $\left(8^{\text {th }}, 10^{\text {th }}\right.$, $12^{\text {th }}$ ), 51.3\% respondents (retail investors) are those who are having the college level education, $15 \%$ respondents (retail investors) are those who are having professional knowledge and the 3\% respondents are those who are doctorates. So, the data indicates that most of the respondents are having college level education i.e., $51.3 \%$ followed by school education which is $30.7 \%$ and the other two categories that are professional, and doctorates are less in percentage or in number (Figure 3).

Occupation of the respondents: Occupations do have a bearing on persons or individuals personality and the ways of investment habits.

\begin{tabular}{|c|c|c|c|c|c|}
\hline S.No & Variable & Frequency & Percent & $\begin{array}{c}\text { Valid } \\
\text { Percent }\end{array}$ & $\begin{array}{c}\text { Cumulative } \\
\text { Percent }\end{array}$ \\
\hline 1 & Male & 176 & 58.7 & 58.7 & 58.7 \\
\hline 2 & Female & 124 & 41.3 & 41.3 & 100 \\
\hline & Total & 300 & 100 & 100 & \\
\hline
\end{tabular}

Source: Primary survey

Table 2: Retail investors Gender distribution.

\section{Gender based Frequency distribution}

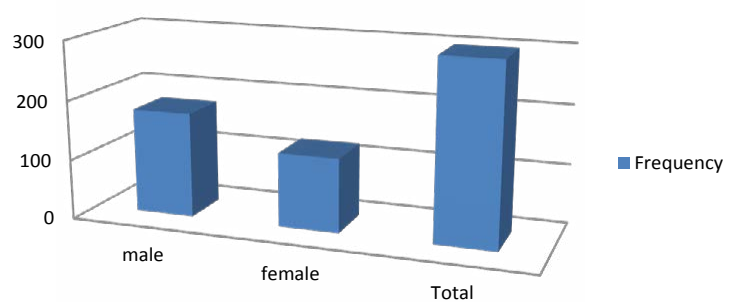

Figure 2: Retail investors gender distribution table.

\begin{tabular}{|c|c|c|c|c|c|}
\hline S.No & Variable & Frequency & Percent & $\begin{array}{c}\text { Valid } \\
\text { Percent }\end{array}$ & $\begin{array}{c}\text { Cumulative } \\
\text { Percent }\end{array}$ \\
\hline 1 & $\begin{array}{c}\text { School } \\
\text { education }\end{array}$ & 92 & 30.7 & 30.7 & 30.7 \\
\hline 2 & $\begin{array}{c}\text { College } \\
\text { education }\end{array}$ & 154 & 51.3 & 51.3 & 82 \\
\hline 3 & Professional & 45 & 15 & 15 & 97 \\
\hline 4 & Others & 9 & 3 & 3 & 100 \\
\hline & Total & 300 & 100 & 100 & \\
\hline
\end{tabular}

Source: Primary survey

Table 3: Qualification of the respondents. 
The quality of life is also determined by an individual's occupation and the incomes he generates or derives from it. Occupations of an investor also socialize him in a particular way which in turn reflects their pattern of behaviors and level of understanding [5]. The person's response to a problem is possibly determined by the type of occupation where he or she is engaged, and hence variable occupation were investigated by the researcher and data pertaining to occupation related is in the below Table 4 .

Interpretation: The data of the above table shows the occupational patterns of the respondents. According to the data of table $28.3 \%$ respondents are those who belongs to the salaried category, $30.3 \%$ respondents are those who belongs to professional category, $29.7 \%$ respondents are those whose belonging are from business category and $11.7 \%$ are those who belongs to other category (speculators, laborers). Therefore, from the data the above two occupational categories which are salaried and professional are higher in percentile than the other two categories which are business and others (speculators, laborers).

Pie chart: Shows the occupation of retail investors separately (Figure 4).

\section{Qualification Frequency distribution of respondents}

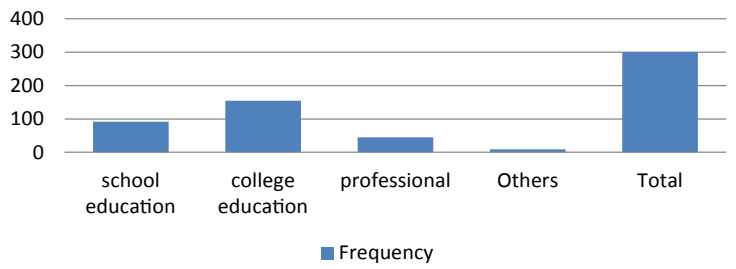

Figure 3: Qualification of the respondents.

\begin{tabular}{|c|c|c|c|c|c|}
\hline S.No & Variable & Frequency & Percent & $\begin{array}{c}\text { Valid } \\
\text { Percent }\end{array}$ & $\begin{array}{c}\text { Cumulative } \\
\text { Percent }\end{array}$ \\
\hline 1 & Salaried & 85 & 28.3 & 28.3 & 28.3 \\
\hline 2 & Professional & 91 & 30.3 & 30.3 & 58.7 \\
\hline 3 & Business & 89 & 29.7 & 29.7 & 88.3 \\
\hline 4 & Other & 35 & 11.7 & 11.7 & 100 \\
\hline & Total & 300 & 100 & 100 & \\
\hline
\end{tabular}

Source: Primary survey

Table 4: Occupation of retail investors.

\section{Occupation distribution of respondents in Percentage}

- Percent

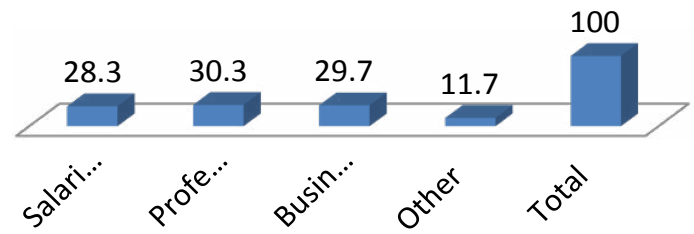

Figure 4: Shows the occupation of retail investors separately.
Income of the respondents: Income is considered as an important variable in shaping the economic stability of an individual. Income is a factor of stable source for investors which attract them towards the various financial investments [6]. Therefore, in this study the researcher investigated the income variable, and the data related to income variable of different investors are presented in the table below given (Table 5).

Interpretation: The Table 6 which represents the monthly income of the retail investors (respondents). The table presents the level of income separately as $24.0 \%$ are having the monthly income of above $20,000,33.0 \%$ are those who are having 20,000 to 40,000 monthly income and $43.0 \%$ are those who are having above 40,000 monthly income. So, the data indicates that the highest numbers of respondents (retail investors) that are $43.0 \%$ are having the highest monthly income rest of the reaming investors (Figure 5).

Residence of the respondents: Residence is one of the important factor which explains the background of a person and it also determines the better investing future of investors towards the various financial investments as investment depend on the living standard of the investor (Table 6).

Interpretation: The above table is all about the residence of respondents that indicates $83.7 \%$ percent respondents are those who are having their own residences and, $16.3 \%$ respondents are those who are living in rented based residences. So, the data shows that most of the respondents who are investing in various financial investments are having their own residences which are 251 in number, and the data also shows that there is less number of investors or respondents who are

\begin{tabular}{|c|c|c|c|c|c|}
\hline S.No & Income & Frequency & Percent & $\begin{array}{c}\text { Valid } \\
\text { Percent }\end{array}$ & $\begin{array}{c}\text { Cumulative } \\
\text { Percent }\end{array}$ \\
\hline 1 & $\begin{array}{c}\text { Above } \\
20000\end{array}$ & 72 & 24 & 24 & 24 \\
\hline 2 & $\begin{array}{c}20000- \\
40000\end{array}$ & 99 & 33 & 33 & 57 \\
\hline 3 & $\begin{array}{c}40000 \text { and } \\
\text { above }\end{array}$ & 129 & 43 & 43 & 100 \\
\hline & Total & 300 & 100 & 100 & \\
\hline
\end{tabular}

Source: Primary survey

Table 5: Monthly Income of retail investors.

\section{Income of respondents in Percentage}

$\sim$ Percent

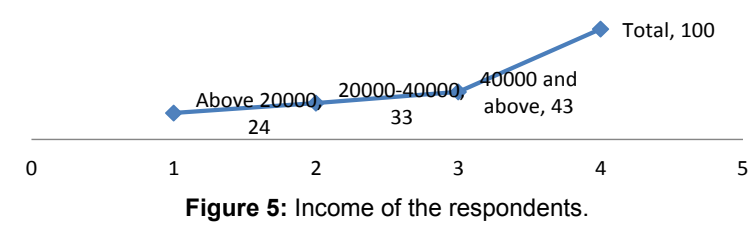

\begin{tabular}{|c|c|c|c|c|c|}
\hline S.No & Variable & Frequency & Percent & $\begin{array}{c}\text { Valid } \\
\text { Percent }\end{array}$ & $\begin{array}{c}\text { Cumulative } \\
\text { Percent }\end{array}$ \\
\hline 1 & Own & 251 & 83.7 & 83.7 & 83.7 \\
\hline 2 & Rented & 49 & 16.3 & 16.3 & 100 \\
\hline & Total & 300 & 100 & 100 & \\
\hline
\end{tabular}

Source: Primary survey

Table 6: Type of residence of retail investors. 
Citation: Bhat AA (2018) Behavior of Retail Investors towards Financial Investments (with Special Reference to Bhopal) towards Various Investment Alternatives. J Bus Fin Aff 7: 336. doi: 10.4172/2167-0234.1000336

Page 4 of 8

doing investment in various financial investments are living their lives in rent based residences (Figure 6).

Work starting age: Work starting age is an initiative of investors towards their investment policies and it plays a vital role towards their perception and experience which build the commandment over the investment (Table 7)

Interpretation: The above table shows the working age of respondents towards the various financial investments. As, 20-30 years of age group are $63.0 \%$ of respondents, 15 to 19 years of age group are $30.0 \%$ of respondents and the age of below 15 years are $7.0 \%$ of respondents. So, the data indicates that 20 to 30 years of age group is dominant towards the financial investments, followed by the age group of 15 to 19 and below 15 years of age group (Figure 7).

Investment experience: Experience is having most important role in investments of the investors. Experience plays a basic role in investor's returns and risks on investments. The more experience any investor has the more he or she can invest in various financial investment and more he or she get return (Table 8).

Interpretation: The above data shows the experience of the respondents in the field of investment as, $8 \%$ are those who are

\section{residence distribution of respondents in Percentage}

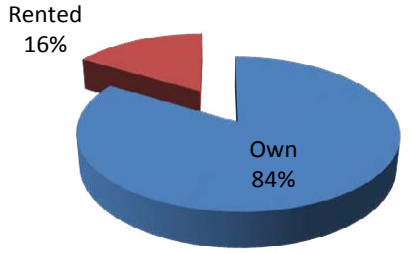

Figure 6: Type of residence of retail investors.

\begin{tabular}{|c|c|c|c|c|c|}
\hline S.No & Variable & Frequency & Percent & $\begin{array}{c}\text { Valid } \\
\text { Percent }\end{array}$ & $\begin{array}{c}\text { Cumulative } \\
\text { Percent }\end{array}$ \\
\hline 1 & $20-30$ years & 189 & 63 & 63 & 63 \\
\hline 2 & $15-19$ & 90 & 30 & 30 & 93 \\
\hline 3 & Below 15 & 21 & 7 & 7 & 100 \\
\hline & Total & 300 & 100 & 100 & \\
\hline
\end{tabular}

Source: Primary survey

Table 7: Retail investors age when they started work.

\section{starting working age Percentage}

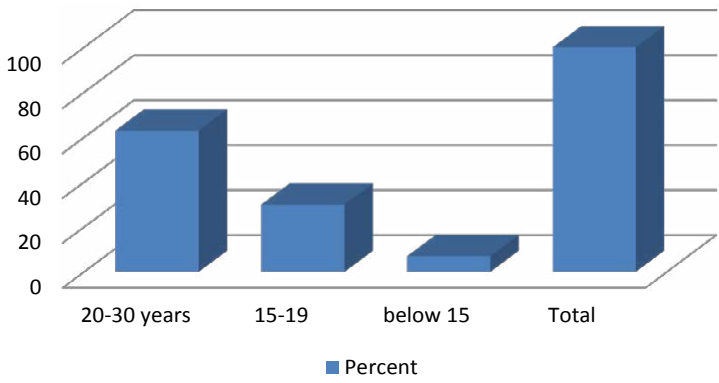

Figure 7: Retail investors age when they started work. having experience of $4-8$ years, $19.3 \%$ are those who are having $2-4$ years of experience and $72.7 \%$ are those who are having up to 2 years of experience regarding the investment. So, the data indicates that the respondents who are having up to 2 years of experience are more in percentile followed by the respondents who are having 2-4 years experience and up to 4-8 years of experience (Figure 8).

Type of investor: Type of Investor provides the category of different investors based on hereditary (family background) investor and new investor. Who invest their funds to grab the new opportunities in the market according to the potential and their needs (Table 9).

Interpretation: The above table shows the type of investors, as $77.0 \%$ of respondents are those who are new investors, and $23.0 \%$ of the respondents are those whose belongings are to the investor's family's backgrounds (hereditary) [7]. So, from the data we understand that the investor who belongs to hereditary type is lesser in number or percentile as compared to the new investors (Figure 9).

Category of investors: Category of investors represents the division among the different investors who invest the savings towards the investment according to their capacity or potential to fulfill their targets (Table 10).

Interpretation: The data in the above table shows the different categories of the investors as $50.0 \%$ of the respondents are day traders, $38.0 \%$ of the respondents are short term investors, $5.0 \%$ of the respondents are long term investors and $7.0 \%$ of the respondents who belongs to all types of investors category. So, from the data its understood that the day traders are the mostly investors in numbers or

\begin{tabular}{|c|c|c|c|c|c|}
\hline S.No & Variable & Frequency & Percent & $\begin{array}{c}\text { Valid } \\
\text { Percent }\end{array}$ & $\begin{array}{c}\text { Cumulative } \\
\text { Percent }\end{array}$ \\
\hline 1 & $4-8$ years & 24 & 8 & 8 & 100 \\
\hline 2 & 2-4 years & 58 & 19.3 & 19.3 & 92 \\
\hline 3 & $\begin{array}{c}\text { Up to 2 } \\
\text { years }\end{array}$ & 218 & 72.7 & 72.7 & 72.7 \\
\hline & Total & 300 & 100 & 100 & \\
\hline
\end{tabular}

Source: Primary survey

Table 8: Retail investor's investment experience.

\section{Experience of respondents in years}

$\diamond$ Frequency

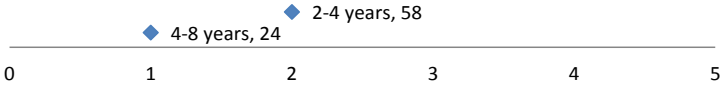

Figure 8: Retail investor's investment experience.

\begin{tabular}{|c|c|c|c|c|c|}
\hline S.No & Variable & Frequency & Percent & $\begin{array}{c}\text { Valid } \\
\text { Percent }\end{array}$ & $\begin{array}{c}\text { Cumulative } \\
\text { Percent }\end{array}$ \\
\hline 1 & $\begin{array}{c}\text { Hereditary } \\
\text { investor }\end{array}$ & 69 & 23 & 23 & 23 \\
\hline 2 & $\begin{array}{c}\text { New } \\
\text { investor }\end{array}$ & 231 & 77 & 77 & 100 \\
\hline & Total & 300 & 100 & 100 & \\
\hline
\end{tabular}

Source: Primary survey

Table 9: Retail investors Type of investor. 


\section{Retail investors Type of investor in Percentage}

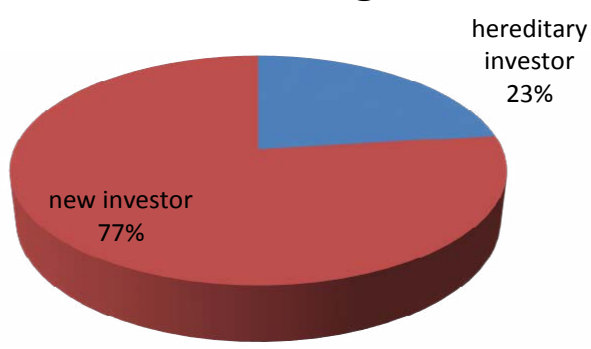

Figure 9: Retail investors type of investor.

\begin{tabular}{|c|c|c|c|c|c|}
\hline S.No & Variable & Frequency & Percent & $\begin{array}{c}\text { Valid } \\
\text { Percent }\end{array}$ & $\begin{array}{c}\text { Cumulative } \\
\text { Percent }\end{array}$ \\
\hline Valid & $\begin{array}{c}\text { Day Trader } \\
\begin{array}{c}\text { Short term } \\
\text { investor }\end{array}\end{array}$ & 150 & 50 & 50 & 50 \\
\hline & $\begin{array}{c}\text { Long term } \\
\text { investor }\end{array}$ & 114 & 38 & 38 & 88 \\
\hline & All & 21 & 5 & 5 & 93 \\
\hline & Total & 300 & 100 & 100 & 100 \\
\hline
\end{tabular}

Source: Primary survey

Table 10: Retail investors category.

in percentile of investors, followed by short term, long term investors and all types of investors category (Figure 10 and Table 11).

Interpretation: The above data table shows the preferences of investment among 300 respondents, as $34.7 \%$ of respondents preferred to invest on shares. $10.0 \%$ of respondents are those who prefer to invest on debentures and bonds, $11.0 \%$ of respondents who prefer to invest their savings on mutual funds, $11.7 \%$ of respondents are those who prefer to invest their money on fixed deposits $20.3 \%$ of respondents who prefer to invest on real estate and $12.3 \%$ of respondents who prefer to investor savings on real estate and gold. So, above data indicates that Most of the $34.7 \%$ of respondents who want to invest their savings on shares and followed by real estate with $20.3 \%$ of respondents (Figure 11).

Marital status: Marriage is one of the most important social institutions, it has undergone many changes. The perceptions and attitudes of the person can also differ by the marital status of the persons because the marriage might make the persons little more responsible and matured in understanding and giving the responses to the questions asked. The details of the marital status of the respondents are presented in Table 12 given below [8].

Interpretation: The above data table indicates the investor's marital status separately most of the investors are 188 which are unmarried, and their percentage is $62.7 \%, 112$ respondents are those who are married, and their percentage is $37.3 \%$ only so, we investigate here most of the investors prefer invest their savings even before marriage (Figure 12).

\section{Hypothesis test and interpretation}

- Hypothesis 1. There is no significant difference between the gender of retail investors towards various financial investments.

- Hypothesis 2. There is no significant difference between the occupations of retail investors towards various financial investments.

\section{Retail investors category Chart}

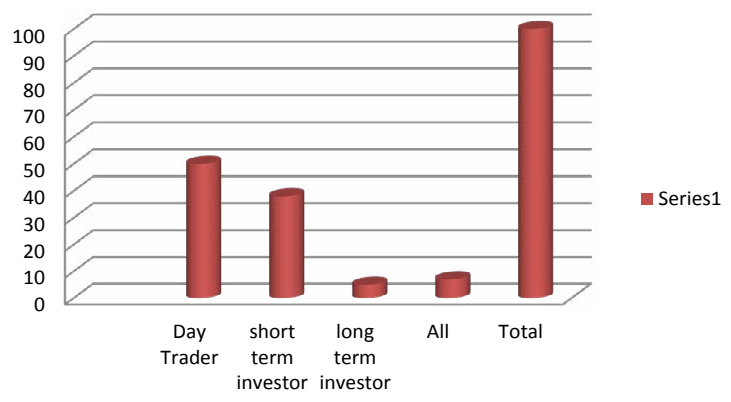

Figure 10: Retail investor's category.

\begin{tabular}{|c|c|c|c|c|c|}
\hline S.No & Variable & Frequency & Percent & $\begin{array}{c}\text { Valid } \\
\text { Percent }\end{array}$ & $\begin{array}{c}\text { Cumulative } \\
\text { Percent }\end{array}$ \\
\hline 1 & $\begin{array}{c}\text { Shares } \\
\text { Debentures/ } \\
\text { bonds }\end{array}$ & 104 & 34.7 & 34.7 & 34.7 \\
\hline 3 & $\begin{array}{c}\text { Mutual } \\
\text { funds }\end{array}$ & 35 & 11.7 & 11.7 & 54.7 \\
\hline 4 & $\begin{array}{c}\text { Fixed } \\
\text { deposits }\end{array}$ & 33 & 11 & 11 & 67.3 \\
\hline 5 & Real estate & 61 & 20.3 & 20.3 & 87.7 \\
\hline 6 & Gold & 37 & 12.3 & 12.3 & 100 \\
\hline & Total & 300 & 100 & 100 & \\
\hline
\end{tabular}

Source: Primary survey

Table 11: Various alternative investments.

\section{Chart for Various Alternative \\ Investments}

Frequency

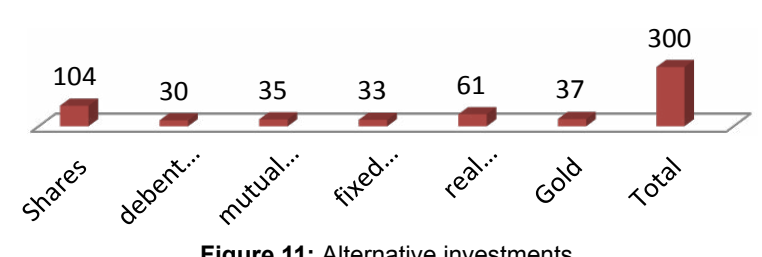

Figure 11: Alternative investments.

\begin{tabular}{|c|c|c|c|c|c|}
\hline S.No & Variable & Frequency & Percent & $\begin{array}{c}\text { Valid } \\
\text { Percent }\end{array}$ & $\begin{array}{c}\text { Cumulative } \\
\text { Percent }\end{array}$ \\
\hline 1 & Married & 112 & 37.3 & 37.3 & 37.3 \\
\hline 2 & Unmarried & 188 & 62.7 & 62.7 & 100 \\
\hline & Total & 300 & 100 & 100 & \\
\hline
\end{tabular}

Source: Primary survey

Table 12: Marital status of retail investors.

\section{Chi-square test}

\begin{tabular}{|c|c|c|c|c|c|}
\hline Gender & $\mathrm{O}$ & $\mathrm{E}$ & $(\mathrm{O}-\mathrm{E})$ & $(\mathrm{O}-\mathrm{E}) 2$ & $(\mathrm{O}-\mathrm{E}) 2 / \mathrm{E}$ \\
\hline Male & 176 & 180 & -4 & 16 & 0.08 \\
\hline Female & 124 & 120 & 4 & 16 & 0.13 \\
\hline Total & & & & & 0.21 \\
\hline
\end{tabular}

$\mathrm{X}^{2}=0.49$

$\mathrm{df}=\mathrm{n}-1$ 


\section{Frequency}

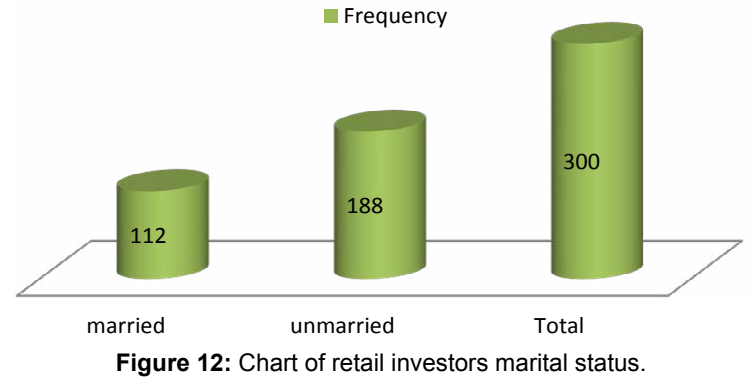

$\mathrm{df}=2-1$

$\mathrm{df}=1$

sig. $=0.05$

T. value $=3.841$.

1. Degree of freedom is $5 \%$ level of significance is 3.84 the calculate vale is $(0.21)$ is less than the table value. So, we can say that our hypothesis there is no significant difference between the gender distributions of retail investors towards various financial investments. It is true, and our hypothesis is proved.

2. Conclusion: Hence it concluded that 'there is no significant difference between the gender distributions of retail investors towards various financial investments'

3. Hypothesis-There is no significant difference between the occupations of retail investors towards various financial investments.

\begin{tabular}{|l|l|l|l|l|l|}
\hline Occupation & O & E & (O-E) & (O-E)2 & (O-E)2/E \\
\hline Salaried & 85 & 88 & -3 & 9 & 0.1 \\
\hline Professional & 91 & 92 & -1 & 1 & 0.01 \\
\hline Business & 89 & 92 & -3 & 9 & 0.09 \\
\hline Other & 35 & 28 & 7 & 49 & 1.75 \\
\hline Total & & & & & 1.95 \\
\hline
\end{tabular}

$\mathrm{x}^{2}=1.95$

$\mathrm{df}=\mathrm{n}-1$

$\mathrm{df}=4-1$

$\mathrm{df}=3$

sig. $=0.05$

T. value $=7.815$

Interpretation: 1 degree of freedom is $5 \%$ level of significance is 7.815 the calculate vale is (1.95) is less than the table value. So, we can say that our hypothesis there is no significant difference between the occupation distributions of retail investors towards various financial investments. Is true and our hypothesis is accepted. Hence, it concluded that 'there is no significant difference between the occupations distributions of retail investors towards various financial investments'

\section{Findings}

This study was about the "behavior of retail investors towards the various financial investments" (with special reference of Bhopal) [9]. In this study 300 respondents were investigated through stratified simple random sampling to know the objectives and hypothesis of the research the data was collected through a well framed questionnaire and then the data were analyzed and tabled in chapter four namely "behavioral profile of retail investors" and the conclusion deduced from that analytical tabled data.

- Regarding the Age of the respondents $74.0 \%$ of 20 to 40 age group, $21.7 \%$ of 40 to 60 age group and $4.3 \%$ of 60 above of age group were investigated to know the behavior of retail investors towards the various financial investments in Bhopal city, because people in these age groups remain active towards financial investments so, age is an important factor which influences the behavior of the individual investors and the investigating ability also differs according to the age of investors. From the data it is clear that the young respondents or investors of age group 20 to 40 (74.0\%) prefer to do invest towards various financial investments and take more risks rest of the other age groups.

- In the present study so for as the gender of the respondents is concerned $58.7 \%$ male respondents and $41.3 \%$ female respondents were investigated. As the study indicates that males are doing more investment than female respondents as the data shows there is high percentage of male respondent's i.e., $58.7 \%$ out $100.0 \%$. So, it is inferred that most of the investment decisions are taken by the male respondents only.

- As the educational backgrounds of the respondent in the present study were investigated $51.3 \%$ or respondents having college level education, $30.7 \%$ having school education $15.0 \%$ with professional education and $3.0 \%$ having others educational qualification like doctorate etc. so the study shows that the respondents who are doing more investment are having college level education and followed by those who are having school level education.

- It was seen through the present study that most of the respondents who were unmarried. I.e., (62.7\%) are observed doing more investments as compared to married i.e., (37.3) ones [10].

- Regarding the Occupation of respondents towards the investment $30.3 \%$ of respondents are of professional, $29.7 \%$ are of business man, $28.3 \%$ are of salaried occupation and $11.7 \%$ are others including lawyers, doctors and so on. Occupation is one of the main deciding factors in the investor's behavior in making investment. People are investing irrespective of their occupation and the study reveals that most of the investors are professional followed by those who are having business category and by salaried.

- It was seen in the study that a high portion $43.0 \%$ of respondents who are having 40,000 above Income are making investments in different financial alternatives more than those who are having 20,000 to 40,000 are $33.0 \%$ respondents and above 20,000 are $24.0 \%$ respondents' monthly income. Income is the important factor without which no investment decisions are to be taken, it is the source and is basic while making investment decisions and the investable amount depends upon the monthly income of the investors. It is observable from the data that most of the respondents (investors) have a monthly income of Rs. 40,000 and above. Regarding the family members the present study discovered the higher percentage of the families $74.0 \%$ who are having 4-6 family members at their families. And present study also found the lower percentage as, $14.3 \%$ families who 
are having less than 4 family members and $11.7 \%$ with above 6 family members [11].

- Regarding the investment options majority of the respondents (investors) have made their investment on shares are $34.7 \%$ and followed by real estate with $20.3 \%$, gold and silver with $12.3 \%$, mutual funds with 11.7 , fixed deposits with $11.0 \%$ and debentures/ bonds with $10.0 \%$ of respondents respectively.

- The present study shown a high portion $83.7 \%$ out of $100 \%$ of respondents are having their own residence of living and the study also reveals that those who are living in rented based dwellings are investing less in number. So, Investment decisions are also depends upon the residence of the investors [12]. As the data of present study understands that only those respondents are investing which are having their own residence instead of those who are having rented based residence [13].

- So, for as the Starting of working age in investment is concerned $63.0 \%$ of 20 to 30 years of age, $30.0 \%$ of 15 to 19 years of age and $7.0 \%$ of below 15 years of age. Here it becomes clear from the data that 20 to 30 years of age are higher in percentage when we check the starting of working age. So, it clears that investment decisions needs investors' maturity [14].

- Regarding the Experience of respondents, the study shows a high percentage $72.7 \%$ of 4 to 8 years of experience followed by $19.3 \%$ of respondents 2 to 4 years and $8.0 \%$ up to 2 years of experience. This shows that the level of experience matters when we check the data the more experienced we found making more investments as of those who are having less experience [15].

\section{Suggestions}

After analyzing the profile of retail investors behavior, we come to know that what are the hurdles do investors face while opt the investments and we came to the findings and conclusion from which point of view we generate some suggestions related to the retail investors interest and which may be helpful form them for upcoming future investments.

- Before entering into the investment investors have to learn a complete knowledge about financial investments.

- The investors has to invest their funds or savings in less risky financial investments like mutual funds, debentures, real estate, gold and silver because these alternatives of financial investments have minimum risk, while compare to other financial investments.

- The investors have to make it their habit to invest their savings as early at their respective ages.

- Investors need to check all types of sources of information because when they learn the information they also can know about the day to day market rates.

- The retail investor can opt the gold bars or gold coins because gold coins have no wastages.

- The real estate investors have to purchase urban land because it will have increase in value day by day.

- Banks also offer saving schemes compared with post office so that investors can save their savings properly in different schemes of banks like saving deposits, fixed deposits etc.

\section{Conclusion}

In respect of providing a conclusion of the behavior of retail investors towards various financial investments. The study has found behavior of retail investors in terms of age, gender, marital status, educational qualification, income, residence, experience, type of investor, and preferences towards investment alternatives, level of risk and returns, post satisfaction on investment, future investment and sources of information.

- According to the study it was observed that mature age group (20-40) plays a vital role in investment.

- So far as the gender is concerned the males were found more investable as compared to the females' investors.

- Regarding the educational background the study indicates that the one who is having more educational level and experience, more he/she can invest and provide good decisions towards the financial investments.

- The occupation is to be found as one of the deciding factors in the investor's behavior while making investment, through this study people were found investing irrespective of their occupations as the study shows that most of the investors who do investments were professionals.

- Income is to be considered as a basic requirement while taking investment decision and the investable amount depends upon the income of the investors, as the present study observed that those who have sound incomes were found doing more investments.

- This study also observed that most of the investors are having their own residence and are more interested in investing residence of retail investors is one of the innovative factors that helps the investors to take part in investments.

- This present study seen new generation are more interested in investment because everyone having future but some of them making safe for upcoming years.

- Regarding the experience of the respondents towards the investment, the study recorded as the investor having more experience and they can make decision towards the investment as the experience matters related to the investment.

\section{References}

1. Shaikh AR, Kalkundarikar AB (2011) Analysis of Retail Investor's Behavior in Belgaum District, Karnataka State. Int J Manag Res 1: 22-39.

2. Brahmabhatt, Kumari PSR, Malekar S (2012) A Study of Investor Behavior on Investment Avenues in Mumbai Fenil. J Marketing Manag Res 1: 49-71.

3. Barberis N, Shleifer A, Vishny R (1998) A model of investor sentiment. J Financ Econ 49: 307-345.

4. Byrne A (2007) Employee saving and investment decisions in defined contribution pension plans: Survey evidence from the UK. Financial Services Review 16: 19-40.

5. Aruna $P$, Rajashekar $H$ (2016) Factors influencing investment decisions of retail investors- A descriptive study. International Journal of Business and Management Invention 5: 06-09.

6. Vankatachalam G, Prabakaran G (2015) A Study on investors' behavior towards gold exchange traded funds in Indian stock market with special reference to Tamil Nadu.

7. Dhanaiah G, Prasad RSR (2015) Acharya Nagarjuna Retail Investors Perception in Financial Markets: A Literature Review and Synthesis. Elk Asia Pacific Journals - Special Issue. 
Citation: Bhat AA (2018) Behavior of Retail Investors towards Financial Investments (with Special Reference to Bhopal) towards Various Investment Alternatives. J Bus Fin Aff 7: 336. doi: 10.4172/2167-0234.1000336

Page 8 of 8

8. Gupta LC (2014) Share Holders Survey: Geographic Distribution. Manas Publications, New Delhi, p: 86

9. Kothari $\mathrm{H}(2015)$ Investors behavior towards investment avenues. Altius Shodh Journal of commerce and management.

10. Jothilingam K, Kannan KV (2011) Investors' attitude towards various avenues - A study Namakkal District. Int J Innov Res Dev 2: 57.

11. James KR (2000) The price of retail investing in the UK. Online social science research.
12. Parimalakanthi K, Kumar MA (2015) A Study pertaining to Investment Behavior of Individual Investors in Coimbatore University. Int J Adv Res Comput Sci Manag Stud 3: 148-157.

13. Kumar A (2009b) Who Gambles in the Stock Market. J Financ 54:1889-1933.

14. Sultana ST (2010) An Empirical Study of Indian Individual Investors Behavior. Glob J Financ Manag 2: 19-33.

15. Bhalla VK (2004) Security analysis and portfolio management. 